Digital Press Social Sciences and Humanities

Technology Acceptance of Grab Mobile Application as Smart Tourism Tools in Bandung City

RR. Adi Hendraningrum, Brainnanda Kevin Christanta, Cindiyosi Harits Ramadhani and Lalu Syafril Rahmadio

Proceeding of Indonesia Heritage Tourism Forum 2019 (IHTF 2019)

Dewi Pratika Ayu Dhira Pradati (eds) 


\title{
Technology Acceptance of Grab Mobile Application as Smart Tourism Tools in Bandung City
}

\author{
RR. Adi Hendraningrum*, Brainnanda Kevin Christanta, Cindiyosi Harits Ramadhani, Lalu Syafril \\ Rahmadio
}

Travel Industry Study, STP NHI Bandung, Bandung, Indonesia

*e-mail: nigrumadi@gmail.com

\begin{abstract}
This research is motivated by a collaboration between the Ministry of Tourism of the Republic of Indonesia and Grab Companies in Indonesia to provide tourism features in Grab Mobile Application. It is hoped that with this collaboration, tourists can use the application to travel and provide benefits. Based on this phenomenon the researcher wants to know how technology acceptance is, by using five factors, namely perceived performance expectancy, perceived effort expectancy, perceived trust, social influence, and perceived quality. This type of research is quantitative research with descriptive statistical research methods. The subjects of this study were 110 users of the Grab mobile application in Bandung. Data collection techniques that are used by researchers is by distributing questionnaires. In this research, we will discuss about 5 UTAUT factors in using the Grab application. The results of the study explained that the five factors show the good category where the perceived performance expectancy factor got score 2131 from 2750 as ideal score, perceived effort expectancy got 1362 from 1650, the perceived trust received 2519 from 3300, social influence got 845 from 1100 and perceived quality got 2854 from 3850. Suggestions regarding the Grab application in this study include intensifying the promotion of the Grab application and its tourism features so that more people are aware of and use the Grab application in tourism activities.
\end{abstract}

\section{Keywords}

smart tourism, smart tourism tools, UTAUT

\section{Introduction}

According to Undang-Undang Republik Indonesia No. 11 Tahun 2009 concerning tourism, tourism is a variety of tourism activities and is supported by facilities and services provided by the local community, fellow tourists, government, local government, and entrepreneurs. In 2019 Indonesia has a target of achieving foreign exchange from the tourism sector of 20 billion rupiah. Which in 2018, Indonesia received 17 billion rupiah of foreign exchange which had increased from year to year. To be able to achieve these targets, one of the efforts needed is to improve facilities and infrastructure such as providing convenience to tourists in seeking information about tourism by utilizing digital technology. Which currently plays an important role in the development of cities in Indonesia. The integration between technology and the city becomes Smart City.

Smart City has a definition of an advanced city at the level of the economy, mobility, human resources, government, environment, and community life are built intelligently, independently, and has awareness from its people (Giffinger et al., 2007 in Esabella, 2016). One of the cities in Indonesia that has implemented the Smart City concept is Bandung. Bandung itself has received many awards, one of them is Smart City Readiness 2017 from PT. Telkom Indonesia and Yokkata Award 2017 in the Smart City category. Smart City encompasses a variety of industries including the tourism industry (Guo et al., 2014 in Boes, K., Buhalis, D., \& Inversini, 2015).

Smart Tourism relies on four core of information and communication technologies, IoT (Internet of Thing), cellular communication, cloud computing, and artificial intelligence technology (Guo et al., 2014 in Smith, 2015). Tussadiyah in Smith, 2015 said an important role in terms of facilitation, the ability to empower and increase the experience of traveling when people utilize personal computers, tablets, and 
smartphones. Therefore, the term Smart Tourism Tools emerged, which have the potential to influence tourist experiences for the better (Smith, 2015).

Smart Tourism Tools is a technology-based instrument or facility that arises from the development of smart tourism concept that is expected to be able to provide benefits to tourists and destinations (Smith, 2015). Smart Tourism Tools are an integration of various concepts of Smart, Tourism, and Tools (Smith, 2015). Smith also specified Smart Tourism Tools in three (3) technologies, which are Augmented Reality, Near Field Communication, and Mobile Application. In this study, researchers focused on the mobile application. The researchers chose the Grab Application as our discussion of this research because some of the functions and benefits that will be delivered by Smart Tourism Tools is to improve or overcome transportation problems.

The Grab application is a mobile application created by the Grab company. The main business of the company is providing online transportation services through both motorbikes and cars. Throughout the journey, the company collaborated with the Ministry of Tourism of Indonesia in October 2018. This collaboration aims to support the Wonderful Indonesia program through a smart tourism strategy by launching a program called \#JelajahIndonesiaLebihDekat. In this cooperation, the Grab application would reveal new features related to tourism, such as All About City dan Grab Rent Car. All About City is a feature inside the application feeds that can give information about tourism such as attractions and culinary in the city where users visit. Meanwhile, Grab Rent Car is a feature so users can rent a car with or without a driver who has tour guide certification.

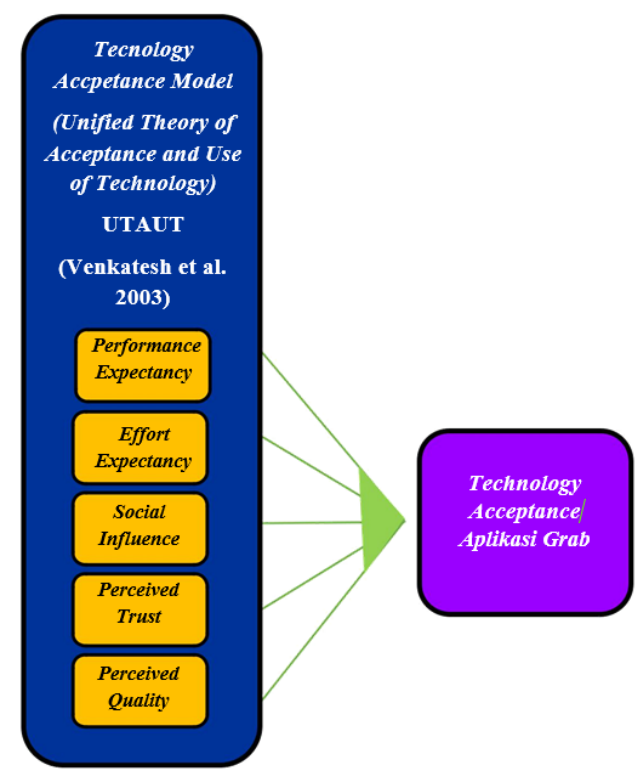

Fig. 1 Conceptual Framework

As a mobile application technology, Grab application is surely used by users, especially tourists, who will look for information about tourism. Based on this phenomenon, researchers are interested in assessing the technology acceptance of Grab application as a smart tourism tool in Bandung, using the theory of Unified Theory of Acceptance and User of Technology (UTAUT). UTAUT is a model that was initiated by Venkatesh et al (2003) by combining eight technology acceptance theories into one, which are:

a. Theory Reasoned Action (TRA)

b. Technology Acceptance Model (TAM)

c. Motivational Model (MM)

d. Theory of Planned Behavior (TPB)

e. Combined TAM and TPB

f. Model of PC Utilization (MPCU)

g. Innovation Diffusion Theory (IDT)

h. Social Cognitive (SCT)

UTAUT has 5 factors that researchers will use in this study, which are perceived performance expectancy, perceived effort expectancy, perceived trust, social influence, and perceived quality (Boes, K., Borde, L., \& Egger, 2015). 
In an activity or job, it is needed a tool that can simplify so that it can support one's activities. Perceived performance expectancy is a measurement used to determine the extent to which an individual's expectations regarding the system he/she uses will help him/her to gain benefits in job performance (Trybou, 2016). Based on the explanation above, the researcher only took a few constructs from performance expectancy, namely perceived usefulness and outcome expectation. In this case, perceived usefulness is defined as the extent to which a person believes that using a particular system will improve the performance of his work, according to Davis et al., 1989 (in Venkatesh, Morris, Davis, \& Davis, 2003) and outcome expectations are defined by Compeau et al., 1999 (in Venkatesh et al., 2003) related to behavioral consequences. Based on empirical evidence, they are separated into performance expectations (related to work) and personal expectations (individual goals). Both of these constructs, the author adjusts to the things that make it easy for tourist activities in the city of Bandung.

Meanwhile, perceived effort expectancy is defined as anticipating the complexity of technology and the level of effort required by individuals when using technology (Venkatesh et al., 2003 in Trybou, 2016). The complexity and level of effort in question is the level of difficulty experienced by individuals when operating technology. When an individual finds it difficult to operate technology, then the effort required will be even greater because it requires time to adjust in the use of technology. The researcher limits the construct by only taking perceived ease of use and complexity. Then, Perceived ease of use is defined as the degree to which a person believes that using a particular system would be free of effort (Davis, 1989). Then, complexity is the extent to which a system is considered relatively difficult to understand and use. Researchers adjust to this study in terms of the effort required by tourists in using the Grab application in the city of Bandung.

Perceived trust relating to the privacy and security of individuals as part of complex interactions with a system (Boes, K., Borde, L., \& Egger, 2015). The concept of trust is related to feeling safe when relying on something or someone. Based on this concept, issues such as security and personal information are complex combinations of interactions that arise due to someone using it with technology. Both security and personal information can be factors that influence technology acceptance. Researchers choose perceived security and perceived privacy as supporters of perceived trust because to get the trust of tourist, we must get a guarantee in terms of security and privacy. Perceived security itself can be interpreted as a threat that creates conditions, conditions, or events with the potential to cause economic difficulties to data or network resources in the form of destruction, disclosure, data modification, denial of service, and / or fraud, waste and abuse (Kalakota and Whinston, 1997 in Carlos Roca, José García, \& José de la Vega, 2009). Meanwhile, perceived privacy is defined as the possibility that online companies collect data about individuals and use it inappropriately (Jarvenpaa and Toad, 1996 in Carlos Roca et al., 2009). This factor is the researcher adjusted with the perception of the confidence of tourists in the city of Bandung in using the Grab application for travel.

Social Influence refers to an individual's belief in the assumptions of others who are considered important and encourages him to have to use the system. (Trybou, 2016). The role of social influence in technology acceptance decisions is complex and subject to various contingent influences. Social influence impacts individual behavior through three mechanisms: compliance, internalization, and identification (Venkatesh \& and Davis, 2000). Researchers only take one construct, which is a subjective norm which can be defined as people's perception that most people who are important to them must or may not conduct the behavior in question (Davis et al., 1989 in Venkantesh 2003).

Perceived quality defined as a consumer rating based on its perception of the superiority of a product or service as a whole (Zeithaml, 1988 in Saputro, 2013). Products form, such as information and services that are relevant, complete, attractive will give a positive perception of someone when using technology. In this study, the assessment focused on the quality of information and the perceived system as a factor influencing the use of technology.

\section{Methods}

The research method in this study is quantitative descriptive. This research was conducted in several tourist attractions in Bandung such as Alun-Alun Bandung, Museum Geologi, Gedung Sate, and Braga Street. The location that the researchers are focusing on is the city of Bandung because it has implemented the smart city concept and the Grab itself has a cooperation agreement with Dinas Pariwisata dan Budaya Kota Bandung. 
Users of Grab application in Bandung are the population selected by researchers. Unfortunately, because the numbers of Grab application users in Bandung cannot be known in advance, the researchers used an infinite population. The sample that the researcher chose was Bandung City tourists who had and used the Grab application which is called Nonprobability sampling and convenient sampling as our withdrawal technique.

Distribution of questionnaires is a technique of collecting data from this research, where the questionnaires become the data collection tool that later would be distributed and filled out by tourists who use and has Grab mobile application. The total numbers of respondents were 110 samples. Before the questionnaires were distributed, the questionnaires are tested for validity and reliability first and the results are valid and reliable. In processing the data, researchers use descriptive analysis which will explain the results of the questionnaire from the respondents who have filled out questionnaires in the form of diagrams and graphs also it will be measured using a Likert scale.

\section{Result and Discussion}

\subsection{Profile}

Respondents in this research were tourists as the users of Grab mobile application. The respondents were dominated by 59 women out of a total of 110 respondents and 51 men. The average age of the respondents was 21-25 as many as $43 \%$ and $34 \%<20$ years. They responded to the new feature released by the Grab mobile application, All About Bandung, that $73 \%$ of respondents did not know the feature and the Grab Rent Car feature, as many as $67 \%$ of respondents already knew this feature.

\subsection{Perceived Performance Expectancy}

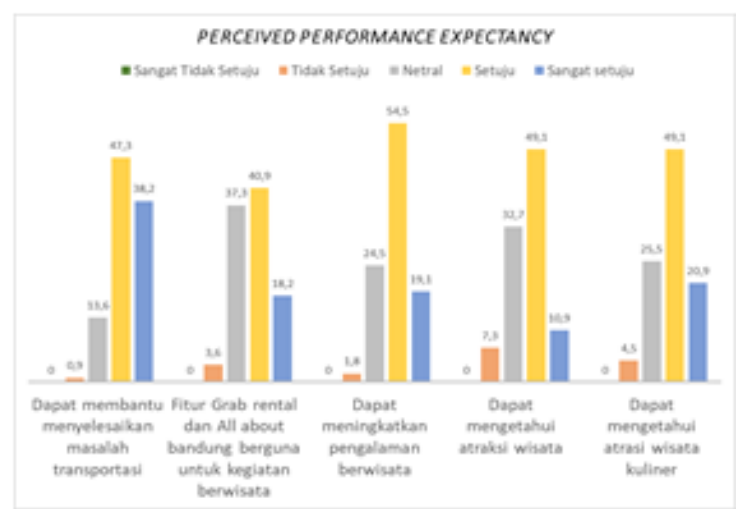

Fig. 2 Perceived Performance Expectancy

The results of the variable perceived performance expectancy indicate that from each question indicators, most of them chose the agreed category. With some of following indicators like "Can help solve transportation problems" as much as 47.3\%, "Grab rental and All about Bandung features are useful for travel activities" as much as 40.9\%, "Can improve the travel experience" as much as 54.5\%, "tourists can know attractions" with 49.1\%, "tourists can know culinary attractions" as much as 49.1\%. This indicates that the Grab application can solve problems that are encountered while traveling in Bandung such as transportation problems when tourists travel in Bandung. 


\subsection{Perceived Effort Expectancy}

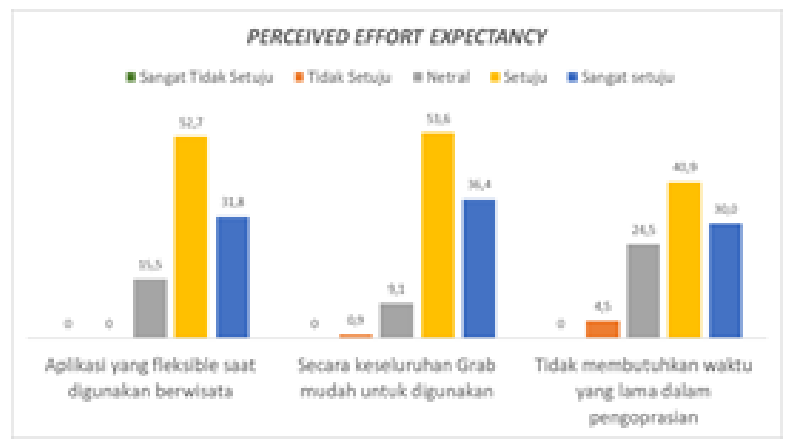

Fig. 3 Perceived Effort Expectancy

The results of the variable perceived effort expectancy indicate that most indicators are dominated by the category of "agree" option, each of the following percentages, such as "Flexible application for traveling" as much as $52.7 \%$, "Overall Grab app is easy to use" as much as $53.6 \%$ and "Does not require a long time in operating" with $40.9 \%$. So, the Grab application can be said to be used easily and does not require a great effort in its use in traveling in the city of Bandung, which also has to be supported by a smooth internet connection.

\subsection{Perceived Trust}

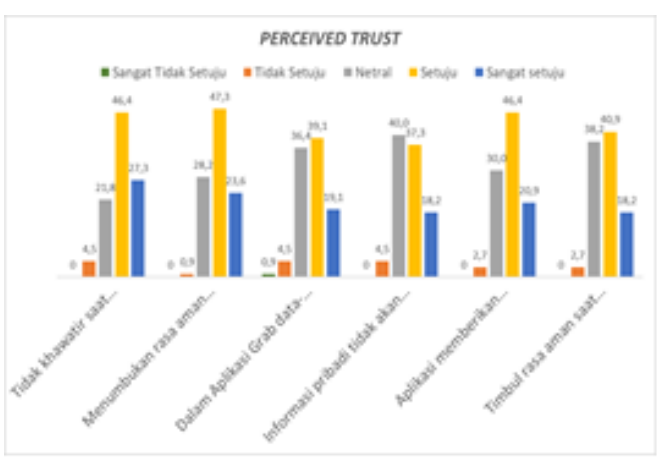

Fig. 4 Perceived Trust

The results of perceived trust variables indicate that most respondents choose the category "agree" with the following indicators. "Will not worry when transacting online with the Grab Application" as much as $46.4 \%$, "Fostering the sense of security when using for traveling" represented by $47.3 \%$, "the personal data I put in Grab Mobile application will not be lost" as much as $40.0 \%$ neutral, "the application provides security guarantees to consumers" with $46.4 \%$, and "there's a sense of security when sharing travel information with others" as much as $40.9 \%$. So, most respondents believe and feel safe when using the Grab application when traveling in the city of Bandung.

\subsection{Social Influence}

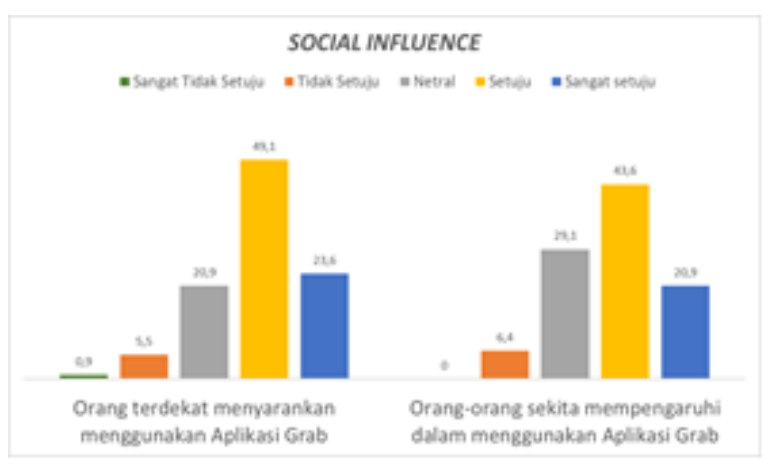

Fig. 5 Social Influence 
The results of the social influence variable indicate that most respondents choose the "agree" category with each percentage as follows. "The closest person recommends using the Grab Application" as much as 49.1\% and "the people around them influence in using the Grab Application" with 43.6\%. So, most respondents believe in other people about the Grab application.

\subsection{Perceived Quality}

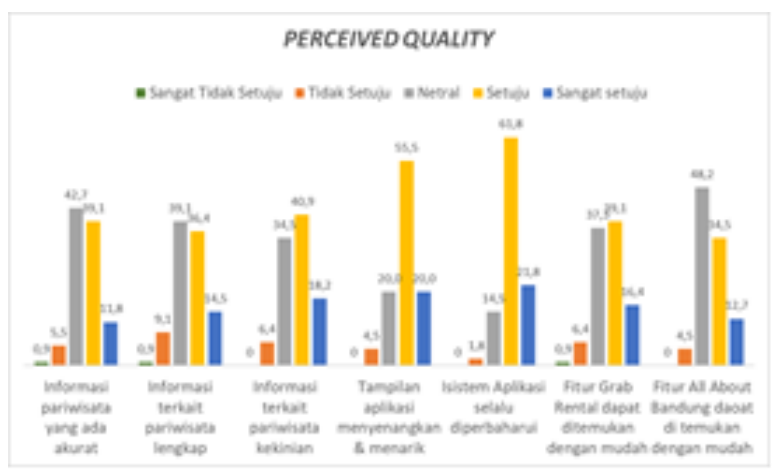

Fig. 6 Perceived Quality

The results of the variable perceived quality show that from the six indicators, three of them are doinantly neutral, the indicators are "The existing tourism information in application is accurate" as $42.7 \%$, tourism-related information is comprehensive" as 39.2\% and "the All About Bandung feature can be found easily" as 48,2\%. Then, the other three are dominated by "agree" with each percentage as follows. "The tourism-related information is contemporary" as 40.9\%, "The appearance of Grab Application is fun \& interesting" as 55.5\%, "Application System is always updated" with 61.8\% and lastly, "Grab Rental Features can be found easily" as much as $39.1 \%$. So, some respondents were still unsure about the quality superiority of the Grab application and some of the respondents also agreed with some of the overall benefits of the Grab application.

\section{Conclusions}

From the results above, it can be concluded that based on the explanation of recapitulation, the factors of perceived performance expectancy consisting of two dimensions, which are perceived usefulness and outcome expectation in the Grab application received an overall score of 2131 or $77.5 \%$ of the ideal score of 2750 and lowest score 550 which is in the good category. The perceived effort expectancy factor consisting of two dimensions, namely perceived ease of use and complexity in the Grab application received an overall score of 1362 or $82.5 \%$ of the ideal score of 1650 and the lowest score of 330 which is in Good category.

The perceived trust factor consisting of two dimensions, which are perceived privacy and perceived security in the Grab application got an overall score of 2519 or $76.3 \%$ of the ideal score of 3300 and the lowest score of 660 which is in the good category. The social influence factor consisting of one dimension with subjective norm got an overall score of 845 or $76.8 \%$ from the ideal score of 1100 and the lowest score of 220 which is in the good category.

Lastly, the perceived quality factor consisting of two dimensions, such as information quality and system quality in the Grab application received an overall score of 2854 or $74.1 \%$ of the ideal score of 3850 and the lowest score of 770 which was in the good category. Therefore, overall assessments according to five factors are in Good category. The use of designated guidelines and instruction-forauthor.pdf will ensure the manuscript to be well-prepared conveniently and properly. 
Acknowledgments This research is supported by the Travel Study Programme, Sekolah Tinggi Pariwisata (STP) NHI Bandung. The authors would like to acknowledge Mrs. Dwiesty Dyah Utami and Mrs. RR. Adi Hendraningrum for their help and support during the project.

\section{References}

Boes, K., Borde, L., \& Egger, R. (2015). The Acceptance of NFC Smart Poster in Tourism. Information and Communications Technologies in Tourism, 435-445.

Boes, K., Buhalis, D., \& Inversini, A. (2015). Conceptualising smart tourism destination dimensions. Information and Communications Technologies in Tourism, 391-403.

Carlos Roca, J., José García, J., \& José de la Vega, J. (2009). The importance of perceived trust, security and privacy in online trading systems. Information Management \& Computer Security, 17(2), 96-113. https://doi.org/10.1108/09685220910963983

Davis, F. D. (1989). Perceived Usefulness, Perceived ease of use, and User Acceptence of inforamtion technology. MIS Quarterly, 13(3), 319-340.

Esabella, S. (2016). Menuju Konsep Smart City.

Saputro. (2013). Pengaruh Perceived Quality, Perceived Sacrifice, dab Perceived Value terhadap Customer Satisfaction di Informas Innovative Furnishing Pakuwon City Surabaya. JURNAL MANAJEMEN PEMASARAN PETRA, 1(1), 1-12.

Smith, K. (2015). SMART Tourism Tools: Linking Technology with the Touristic Resources of City Destinations. Breda: NHTV Breda University of Applied Sciences.

Trybou, J. (2016). Performance Expectancy, Effort Expectancy and Social Influence as Factors Predicting The Acceptance of (Non-) Fluoroscopy-Guided Positioning For Radiographs, and The Relationship with Lead-ership. Gent: Universiteit Gent.

Venkatesh, V., \& and Davis, F. D. (2000). A Theoretical Extension of the Technology Acceptance Model: Four Longitudinal Field Studies. Management Science, 46(2), 186-504.

Venkatesh, V., Morris, M. G., Davis, G. B., \& Davis, F. D. (2003). User Acceptance of Information Technology. MIS Quarterly, 27(3), 425-478. 